\title{
MODIFIED ATMOSPHERE PACKAGES FOR FRESH SQUASH FRUITS STORAGE
}

\author{
Heba R. Sayed-Ahmed*, Adel H. Bahnasawy**, \\ Taha H. Ashour** and Khaled S. Nagy***
}

\begin{abstract}
\end{abstract}
The main aim of this study is to investigate the effect of modified atmosphere (MA) on the quality of squash during storage. Squash fruits were stored at three levels of $\mathrm{O}_{2}$ concentrations (1, 3 and 5\%), three levels of $\mathrm{CO}_{2}$ concentrations (2, 6 and 10\%) under cold storage at $10{ }^{\circ} \mathrm{C}$ and $70 \%$ relative humidity as compared with storage in normal air (22C and 70\%RH) in perforated and non-perforated packages. CO2, O2 and ethylene inside the packages were recorded. Also, weight loss, hardness and color of fruits were determined. The obtained results indicated that, the concentration $\mathrm{CO}_{2}$ inside the package of fresh squash during storage ranged from 4.71 to $24.02 \%$ for all treatment. The $\mathrm{CO}_{2}$ and ethylene concentrations inside the package increases with increasing $\mathrm{CO}_{2}$ and $\mathrm{O}_{2}$ levels during storage, while, $\mathrm{O}_{2}$ concentrations inside the package decreases with increasing $\mathrm{CO}_{2}$ and $\mathrm{O}_{2}$ levels during storage. The accumulated weight loss of squash increased from 0 to 2.17, 0 to 2.48 and 0 to $2.80 \%$, when the storage period increased from 0 to 14 days at 1, 3 and 5\% $\mathrm{O}_{2}$ levels, respectively compared to $35 \%$ for normal air (traditional storage). The squash hardness slightly decreased with storage time, the MA storage had slight effect on the hardness. Package perforation obtained a good results in terms of weight loss compared to the traditional storage. The colour $\left(L^{*}\right)$ of squash decreases with increasing $\mathrm{CO}_{2}$ level during storage period.

Keywords: Squash, Modified atmosphere, Quality, Perforation, shelf life

\footnotetext{
* Assist. Lecturer of Agric. Eng., Fac. of Agric., Benha Univ., Egypt.

** Prof. of Agric. Eng., Fac. of Agric., Benha Univ., Egypt.

*** Head of Researcher of Food Eng., Food Tech. Res. Ins. Agric. Res. Center, Giza, Egypt.
} 


\section{INTRODUCTION}

quash fruits are perishable living tissues that continue to respire after harvest. Respiration and transpiration affecting the quality of the stored commodities. Deterioration and spoilage are also affecting the shelf life of it. To prolong the shelf life and keep quality of perishables is by using cooling and maintaining the produce at low temperatures (Ryall and Lipton, 1979 and Mitchell, 1992). Another technique, especially as a complement to temperature management, is modification of the atmosphere surrounding the product to create a new atmosphere that usually has a lower level of $\mathrm{O}_{2}$ and a higher level of $\mathrm{CO}_{2}$. At these levels of $\mathrm{O}_{2}$ and $\mathrm{CO}_{2}$, the respiration rate of most commodities will decrease, and their shelf-life will be extended (Geeson, 1990).

The modified atmosphere (MA) has a great success in many vegetables. This technique consists of an increase in the partial pressure of the $\mathrm{CO}_{2}$ and a decrease in the $\mathrm{O}_{2}$ (Silveira $e t$ al., 2014), caused by the gas exchanges of the container with the ambient air. The packaging with low partial pressure of oxygen can reduce the respiration rate and maintain the shelf-life for a longer time or with better quality than the package with normal air. However, the extremely low oxygen content may result, in some cases, in fermentation resulting in an accumulation of unpleasant odors and tastes, reducing the aroma biosynthesis and tissue damage ( $\mathbf{L i}$ et al., 2014). In this type of atmosphere, the partial pressure of $\mathrm{O}_{2}$ and $\mathrm{CO}_{2}$ are not controlled, and vary with time, temperature, type of film and the respiratory rate of the product (Chitarra and Chitarra, 2005).

Several packaging techniques and materials may be used in MAP: polymeric films, rigid plastic trays or preformed pouches closed by heat sealing (Geeson et al., 1985, Barmore, 1987, Geeson et al., 1988 and Talasila et al., 1995a) and perforations in otherwise impermeable packages. In the case of polymeric films, the proper atmosphere is obtained by selecting a film with the right gas transmission rate and having the appropriate surface area for the package. For impermeable plastics, the package gas permeability may be achieved by using perforations (Geeson et al., 1988 and Emond et al., 1991). Emond and Chau (1990) proposed the use of perforations for products requiring high $\mathrm{CO}_{2}(10-20 \%)$ with low levels of $\mathrm{O}_{2}(2-10 \%)$. Because their 
permeability ratios are close to one, perforation systems can obtain a high $\mathrm{CO}_{2}$ concentration without reducing the $\mathrm{O}_{2}$ concentration inside the package below critical levels tolerated by the product.

With whole zucchini squash fruit, a $1 \% \mathrm{O} 2$ atmosphere at $2.5 \mathrm{C}$ (Wang and $\mathrm{Ji}, 1989$ ) or $5 \% \mathrm{CO} 2$ at 5C (Mencarelli, 1987) reduced chilling injury and subsequent decay. A $2 \% \mathrm{O} 2$ at $10 \mathrm{C}$ was reported to minimize development of off flavor, which was more pronounced in cooked than in raw fruit (Mencarelli et al., 1983). Slices of zucchini squash may tolerate $\mathrm{O} 2$ atmosphere of $1 \%$ because they do not have a continuous barrier to gases. The distance of gas diffusion is less in slices than whole fruit, which would result in a smaller gradient of O2. Equally important is the determination of the minimum $\mathrm{O} 2$ level that zucchini squash slices could tolerate in MA of film wrapped packages held at 5 to $10 \mathrm{C}$.

Modified atmosphere packaging (MAP) is a postharvest tool used to preserve quality of various fresh whole and minimally processed fruit and vegetables. MAP relies on the dynamic process of alteration of gaseous composition inside a package determined by permeability of packaging film and produce respiration. However, barrier properties to gases $\left(\mathrm{O}_{2}\right.$ and $\mathrm{CO}_{2}$ ) and water vapour limit MAP applicability of many commercial polymeric films (Mangaraj et al., 2009). Conventional (passive MAP) that uses high barrier polymeric films are characterized by the generation of unsuitable in package gas composition, condensation of water vapour and subsequent microbial growth causing loss of quality and impaired shelf-life (Mistriotis et al., 2011).

One way to prolong the shelf life and keep quality of perishables is by cooling and maintaining the produce at low temperatures and using the modified atmosphere storage, therefore, the main aim of this study is to investigate the effect of modified atmosphere levels and package perforation on the quality and shelf life of fresh squash fruits during storage.

\section{MATERIALS AND METHODS}

The experiment was carried out at Agricultural and Bio-Systems Engineering Department Faculty of Agriculture Moshtohor, Benha University, Egypt and Food Technology Research Institute, Agriculture Research Center, during 2018 season. 


\subsection{Raw Materials:}

Squash (Cucurbita pepo L.) was brought from the Experimental Research Station at the Faculty of agriculture, Moshtohor, Benha University after harvesting at the same maturity stage. Squash fruits washed and inspected for any damage and infection.

\subsection{Methods:}

Experiment was divided into two parts, first part was devoted to study the effect of atmospheric modification by raising $\mathrm{CO}_{2}$ and lowering $\mathrm{O}_{2}$. Second part was devoted to study the effect of package perforations compared to traditional storage as shown in table (1). Three levels of $\mathrm{O}_{2}$ and $\mathrm{CO}_{2}$ were used $\left(1,3\right.$ and $\left.5 \% \mathrm{O}_{2}\right)$ and $\left(2,6\right.$ and $\left.10 \% \mathrm{CO}_{2}\right)$. Squash Fruits were placed in package at a rate of $200 \mathrm{~g}$ per package. Packages were divided into two groups. One group for gas modification and the others were perforated at a rate 10, 20 and 30 punches packages $(0.962$, 1.934 and $2.886 \mathrm{~mm} 2$ surface areas).

\subsubsection{Experimental design:}

The treatments were arranged in a split plot design in three replications. Table (1) shows the experimental design.

Table (1): The experimental design.

\begin{tabular}{|l|l|c|c|l|}
\hline No. & Independent variables & $\begin{array}{l}\text { Runs } \\
\text { No. }\end{array}$ & $\begin{array}{l}\text { Levels } \\
\text { No. }\end{array}$ & $\begin{array}{l}\text { Independent } \\
\text { levels }\end{array}$ \\
\hline \multirow{2}{*}{1} & Gas modification & 3 & 3 & \multicolumn{1}{|l|}{ Oxygen: 1,3 and 5\% } \\
\cline { 2 - 5 } & 3 & 3 & $\begin{array}{l}\text { Carbon Dioxide: 2, 6 and } \\
10 \%\end{array}$ \\
\hline 2 & Perforation (normal air) & 3 & 3 & $\begin{array}{l}\text { Numbers: 10, 20 and } 30 \\
\text { punches }\end{array}$ \\
\hline 3 & Control & 3 & 1 & Traditional stoage \\
\hline $\begin{array}{l}\text { Total runs }=9 \text { Gas modification } \times 3 \text { runs }+3 \text { Perforations } \times 3 \text { runs }+1 \text { Control } \\
\times 3 \text { runs }=39 \text { runs. }\end{array}$
\end{tabular}

\subsubsection{Measurements:}

$\mathrm{O}_{2}, \mathrm{CO}_{2}$ and ethylene were measured by Gas Analyzer (Model F-95 Range 0 to $200 \pm 0.1 \mathrm{ppm}$ for ethylene, 0 to $100 \pm 0.01 \%$ for $\mathrm{CO}_{2}$ and 0 to $100 \pm 0.1 \%$ for $\mathrm{O}_{2}$, USA) within the closed system after the 4, 8, 12 and 14 days period. Before any measurement was taken, the equipment was 
calibrated. Calculation of the respiration rate was done using the formula below as stated by Saltveit (2004):

$$
\text { respiration rate }(\mathrm{ml} / \mathrm{kg} \cdot \mathrm{hr})=\frac{\mathrm{V}_{\mathrm{c}} \times \% \mathrm{CO}_{2}}{\mathrm{~W}_{\mathrm{p}} \times T \times 100}
$$

Where:

$\mathrm{V}_{\mathrm{c}}$ is the volume package (L)

$\mathrm{W}_{\mathrm{p}}$ is the weight of sample $(\mathrm{kg})$

$\mathrm{T}$ is the time (hr)

Samples were taken after the 4, 8, 12 and 14 days period to determine the moisture loss. Squash samples were weighed by electric digital balance (Model HG - 5000 - Range 0 - $5000 \mathrm{~g} \pm 0.01 \mathrm{~g}$, Japan) before and after drying.

The hardness was measured weekly by Hardness meter (Model GY-1Range $2-15 \mathrm{~kg} \mathrm{~cm}^{-2} \pm 0.1 \mathrm{~kg} \mathrm{~cm}^{-2}$, China). The surface color of squash fruits for each sample was measured with a chroma meter (Model CR300, Minolta, Japan) and results were expressed as $\mathrm{L}^{*}$ and hue angle (arctangent $\left\{\mathrm{b}^{*} / \mathrm{a}^{*}\right\}$ ) values (Izumi and Watada, 1995).

\section{RESULTS AND DISCUSSION}

\subsection{Concentration $\mathrm{CO}_{2}$ inside the package of squash:}

Figures ( $1 \mathrm{a}, \mathrm{b}$ and $\mathrm{c})$ show the effect of modified atmosphere condition (different levels of $\mathrm{O}_{2}$ and $\mathrm{CO}_{2}$ ) on the respiration rate of fresh squash in package. It could be seen that storing squash in different levels of $\mathrm{O}_{2}(1,3$ and 5\%) and $\mathrm{CO}_{2}(2,6$ and 10\%) in a closed (non-perforation) package caused an accumulation of $\mathrm{CO}_{2}$ inside the package. $\mathrm{CO}_{2}$ concentration recorded $15.99 \%$ after 14 days storage at $1 \% \mathrm{O}_{2}$ and $2 \% \mathrm{CO}_{2}$ levels, while it reached the highest concentration $(24.02 \%)$ for the $5 \% \mathrm{O}_{2}$ and $10 \% \mathrm{CO}_{2}$ level treatment after the same period.

The $\mathrm{CO}_{2}$ concentration inside the package increases with increasing $\mathrm{CO}_{2}$ and $\mathrm{O}_{2}$ levels during experimental period, at $1 \% \mathrm{O}_{2}$ concentration, $\mathrm{CO}_{2}$ concentration inside the package increases from 6.18 to $7.88,8.49$ to $10.43,12.54$ to 15.03 and 15.99 to $21.94 \mathrm{mg} / \mathrm{kg}$.hr when the $\mathrm{CO}_{2}$ level increased from 2 to $10 \%$ after 4, 8, 12 and 14 days, respectively. At $3 \%$ $\mathrm{O}_{2}$ concentration, $\mathrm{CO}_{2}$ concentration inside the package changed from $4.71-23.55 \%$ depending on $\mathrm{CO}_{2}$ treatment. At $5 \% \mathrm{O}_{2}$, the least $\mathrm{CO}_{2}$ 
concentration $(5.91 \%)$ was recorded at $2 \% \mathrm{CO}_{2}$ in package after 4 days, while the highest $\mathrm{CO}_{2}$ level $(24.02 \%)$ was recorded at $10 \% \mathrm{CO}_{2}$ treatment after 14 days.

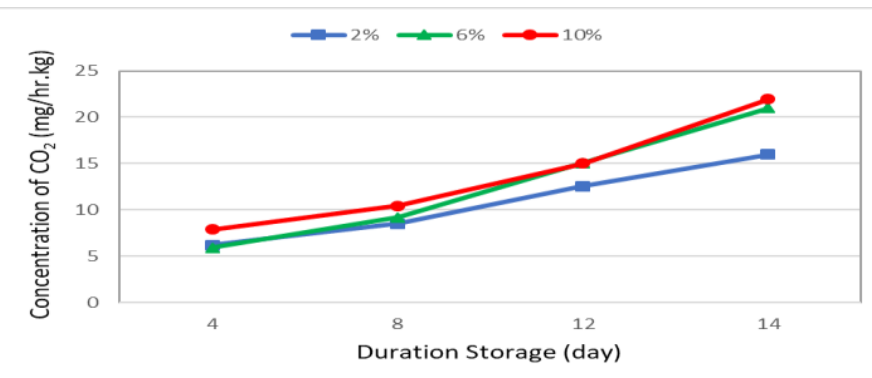

a

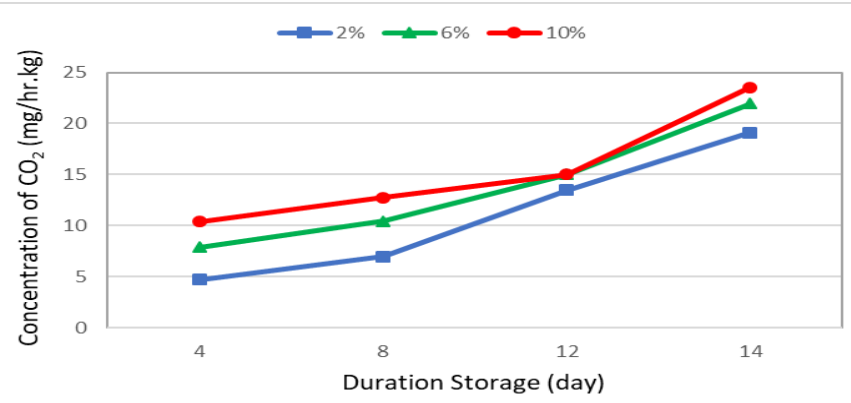

b

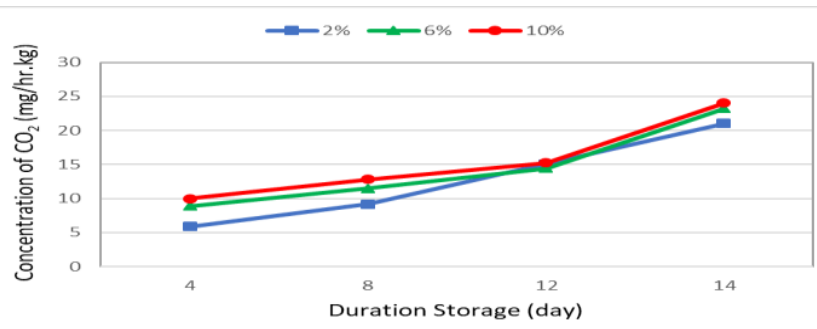

c

Figure (1): The effect of modified atmosphere condition (different levels of $\mathrm{O}_{2}$ and $\mathrm{CO}_{2}$ ) on the concentration $\mathrm{CO}_{2}$ inside the package of fresh squash during storage.

Regarding the effect of perforation the $\mathrm{CO}_{2}$ concentration inside the package as shown in figure (2), the results indicate that the $\mathrm{CO}_{2} \%$ decreased with increasing the perforation, where it was $5.49 \%$ for 10 punches after 4 days and decreased to $3.91 \%$ for $30 \mathrm{P}$ after the same period. After 14 days storage $\mathrm{CO}_{2}$ decreased to $3.54 \%$ for the $30 \mathrm{P}$ packages while it was $1.38 \%$ for $10 \mathrm{P}$ package after the same period. 
Perforation had lowered the $\mathrm{CO}_{2}$ accumulation. $\mathrm{CO}_{2}$ accumulation is depending on perforation surface area. Perforation was drilled through the package. PET plastic container of volume $1250 \mathrm{ml}$ capacity. 10, 20 and 30 holes with diameter of $0.35 \mathrm{~mm}$ with area $0.961,1.92$ and $2.88 \mathrm{~mm}^{2}$ surface areas.

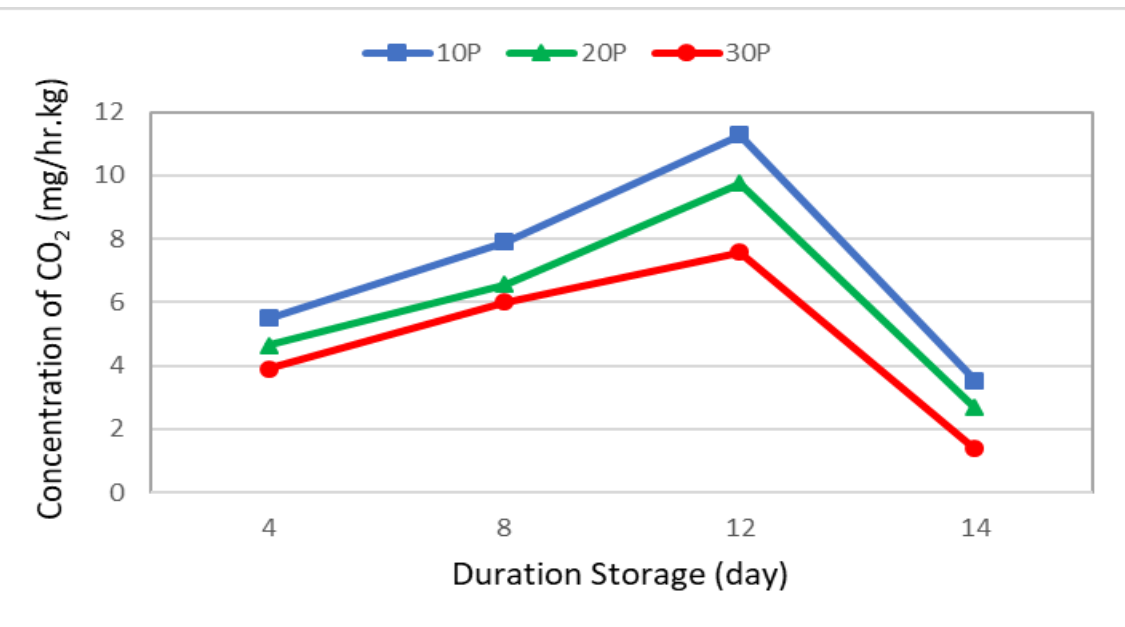

Figure (2): The effect of different perforation surface areas on the concentration $\mathrm{CO}_{2}$ inside the package of fresh squash during storage.

\subsection{Concentration $\mathrm{O}_{2}$ inside the package:}

Figure (3) shows the $\mathrm{O}_{2}$ concentration inside the squash package during storage as affected by different levels of $\mathrm{O}_{2}$ and $\mathrm{CO}_{2}$ concentration. The results show that with increasing the $\mathrm{O}_{2}$ inside the package. The concentration of $\mathrm{O}_{2}$ decreased with storage time, where it decreased slightly by increasing $\mathrm{CO}_{2}$ inside the package. It changed from 1 to $1.63 \%$ at $1 \% \mathrm{O}_{2}$ with changing $\mathrm{CO}_{2}$ from $2-10 \%$, from $1.8-3.67 \%$ at $3 \%$ and $3.53-7.5 \%$ at $5 \% \mathrm{O}_{2}$.

At $1 \% \mathrm{O}_{2}$, the $\mathrm{O}_{2}$ inside the package decreased from 1.36 to $1.03 \%$ depending on different $\mathrm{CO}_{2}$ levels from 2-10\%. At $3 \% \mathrm{O}_{2}$, the $\mathrm{O}_{2}$ decreased from $3.67 \%$ to $1.8 \%$, meanwhile, it decreased from 7.5 to $3.53 \%$ at the higher $\mathrm{O}_{2}$ level inside the packages. It could be seen from the results that the $\mathrm{O}_{2}$ depletion increased with time of storage (4 - 14 days) and $\mathrm{O}_{2}$ level inside the package and decreased by increasing $\mathrm{CO}_{2}$ level inside the package. 


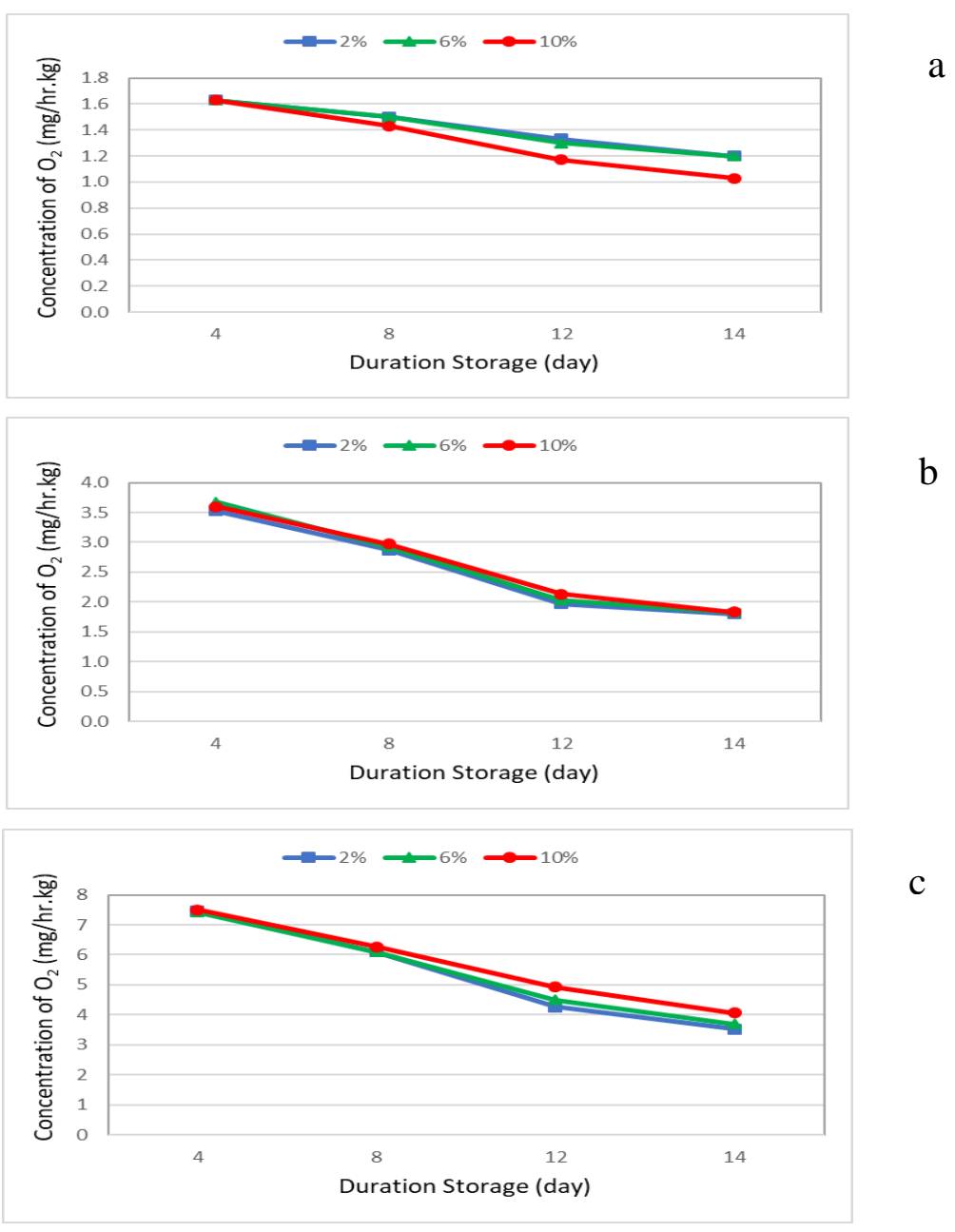

Figure (3): The effect of modified atmosphere condition (different levels of $\mathrm{O}_{2}$ and $\mathrm{CO}_{2}$ ) on the concentration $\mathrm{O}_{2}$ inside the package of fresh squash during storage.

Regarding the effect of perforation, it could be seen that the perforation has a great effect on the depletion of $\mathrm{O}_{2}$, where $\mathrm{O}_{2}$ decreased from 1.63 to $0.57 \%$ for the packages while have $10 \mathrm{P}$ (area $3.85 \mathrm{~mm}^{2}$ ), from 1.50 to $0.23 \%$ and 1.43 to 0.13 for 20 and $30 \mathrm{P}$ packages, respectively as shown in figure (4).

\subsection{Concentration $\mathrm{C}_{2} \mathrm{H}_{4}$ inside the package:}

Figures (5 a, b and c) show the effect of different levels of $\mathrm{O}_{2}(1,3$ and $5 \%)$ and $\mathrm{CO}_{2}(2,6$ and $10 \%)$ inside the squash packages on the level of 
producing ethylene during storage. The results indicated that the ethylene concentration inside the package decreases with increasing $\mathrm{CO}_{2}$ level during storage period. It could be seen that, when the $\mathrm{CO}_{2}$ concentration increased from 2 to $10 \%$, the ethylene concentration inside the package decreased from 5.27 to $2.35,22.00$ to $14.90,35.60$ to 29.33 and 67.40 to $39.23 \%$ after $4,8,12$ and 14 days, respectively at $1 \% \mathrm{O}_{2}$ level. At $3 \% \mathrm{O}_{2}$ level, the ethylene concentration inside the package decreased from 8.10 to $6.23,27.67$ to $8.00,48.97$ to 34.80 and 95.33 to $75.57 \%$ after $4,8,12$ and 14 days, respectively, when the $\mathrm{CO}_{2}$ concentration increased from 2 to $10 \%$. At $5 \% \mathrm{O}_{2}$ level, the ethylene concentration inside the package decreased from 29.07 to $8.67,45.27$ to $15.53,62.07$ to 50.40 and 150.57 to $107.27 \%$ after $4,8,12$ and 14 days, respectively, when the $\mathrm{CO}_{2}$ concentration increased from 2 to $10 \%$. High $\mathrm{CO}_{2}$ concentration inhibit the generation of $\mathrm{C}_{2} \mathrm{H}_{4}$ because it can influence the enzyme activity.

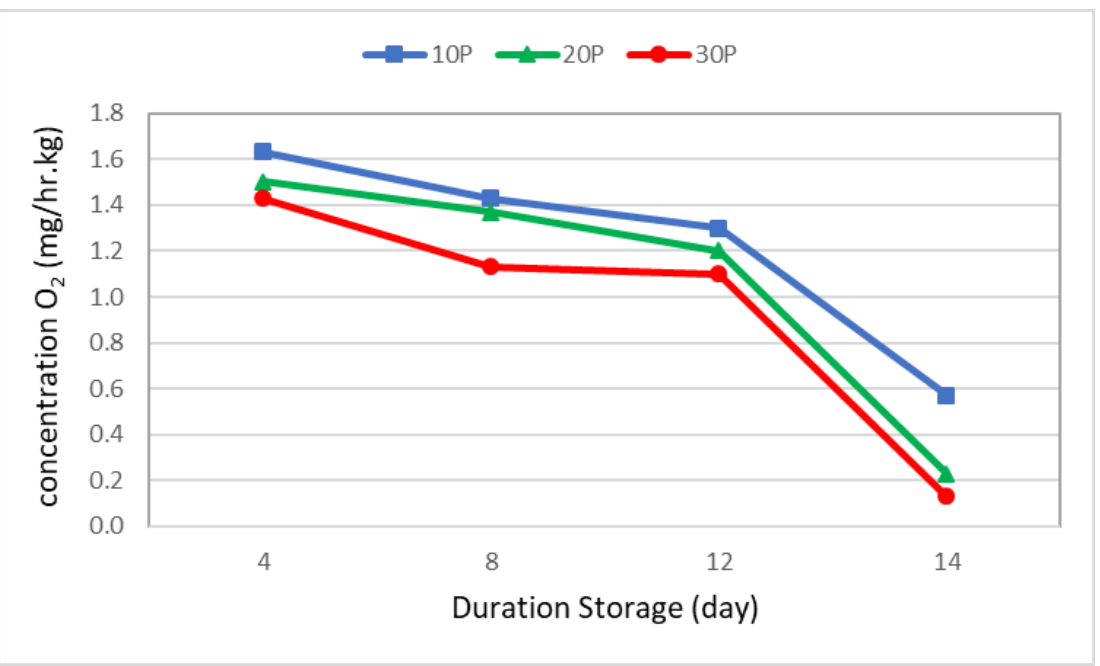

Figure (4): Effect of different perforation surface areas on the concentration $\mathrm{O}_{2}$ inside the package of fresh squash during storage.

The results indicate that the ethylene concentration inside the package increases with increasing drying period. It could be seen that the ethylene concentration inside the package increased from 4.11 to $51.64,7.23$ to 86.50 and 18.37 to $126.68 \%$, when the storage period increased from 4 to 14 days at 1,3 and $5 \% \mathrm{O}_{2}$ levels, respectively. 


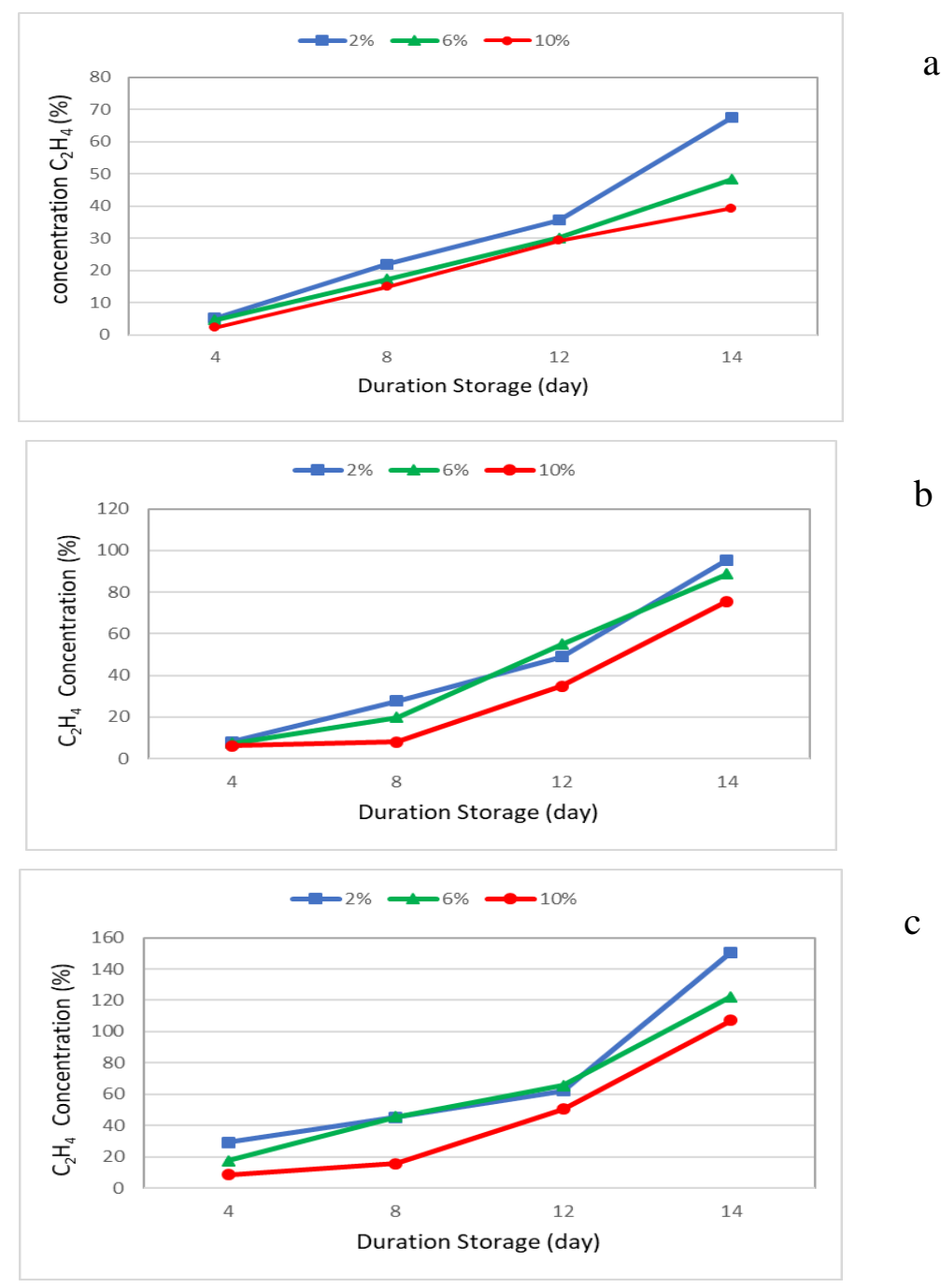

Figure (5): The effect of modified atmosphere condition on the ethylene concentration inside the package of fresh squash during storage.

Regarding the effect of punching the package, the results indicate that, the $\mathrm{C}_{2} \mathrm{H}_{4}$ level decreases with increasing the number of punches from 10 to $30 \mathrm{p}$ as shown in figure (6). It could be seen that the ethylene concentration inside the package decreased from 9.13 to $3.00,21.80$ to $12.30,31.43$ to 15.93 and 44.93 to $26.23 \%$, when the perforation level surface area increased from 10 to 30 punches packages after 4, 8, 12 and 14 days, respectively. 


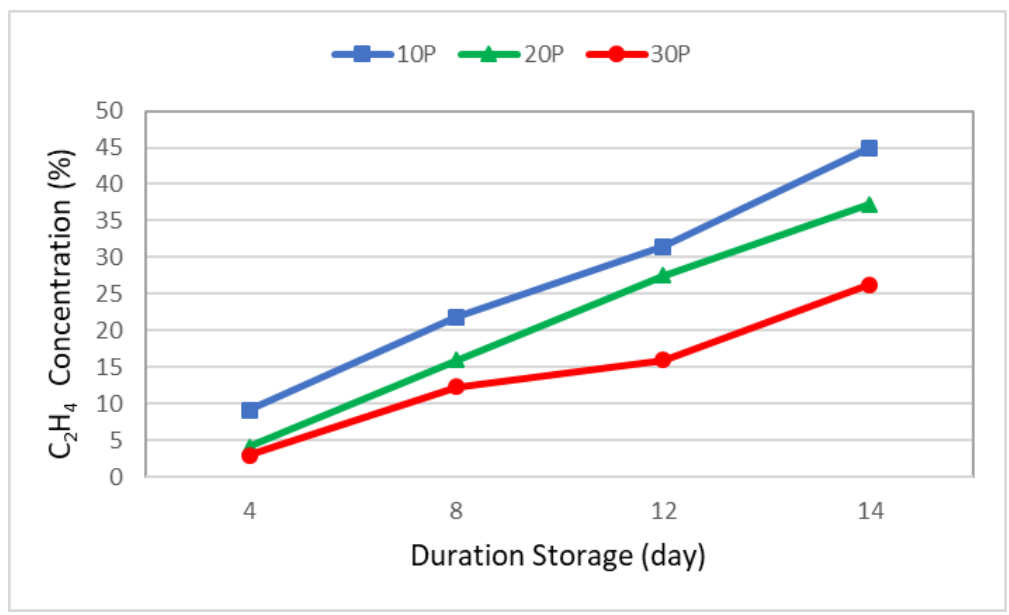

Figure (6): Effect of different perforation level surface area on the concentration $\mathrm{C}_{2} \mathrm{H}_{4}$ inside the package of fresh squash during storage

\subsection{Accumulation weight losses:}

Figures ( $7 \mathrm{a}, \mathrm{b}$ and $\mathrm{c}$ ) show the effect of different $\mathrm{O}_{2}$ and $\mathrm{CO}_{2}$ levels on accumulated weight losses inside the package of fresh squash during storage. The results indicated that the accumulated weight losses decrease with increasing $\mathrm{CO}_{2}$ and $\mathrm{O}_{2}$ levels during storage period. It could be seen that, when the $\mathrm{CO}_{2}$ concentration increased from 2 to $10 \%$, the accumulated weight losses decreased from 1.27 to 1.12 and 2.31 to 1.97 $\%$ after 7 and 14 days, respectively at $1 \% \mathrm{O}_{2}$ level. At $3 \% \mathrm{O}_{2}$ level, the accumulated weight losses decreased from 1.45 to 1.32 and 2.69 to 2.32 $\%$ after 7 and 14 days, respectively, when the $\mathrm{CO}_{2}$ concentration increased from 2 to $10 \%$. At $5 \% \mathrm{O}_{2}$ level, the accumulated weight losses decreased from 1.99 to 1.76 and 3.40 to $1.97 \%$ after 7 and 14 days, respectively, when the $\mathrm{CO}_{2}$ concentration increased from 2 to $10 \%$.

The results indicate that the accumulated weight loss of squash fruits increases with increasing drying period. It could be seen that the accumulated weight loss of squash increased from 0 to $2.17,0$ to 2.48 and 0 to $2.80 \%$, when the storage period increased from 0 to 14 days at 1,3 and $5 \% \mathrm{O}_{2}$ levels, respectively.

The results also indicted that, the accumulated weight loss as affected by the levels of $\mathrm{O}_{2}$ and $\mathrm{CO}_{2}$ inside the package of squash during storage. WL were greatly reduced by reducing $\mathrm{O}_{2}$ and elevating $\mathrm{CO}_{2}$ in the packages 
PROCESS ENGINEERING

the highest WL (3.40) recorded when squash stored at 5\% $\mathrm{O}_{2}$ level and 2 $\% \mathrm{CO}_{2}$ level compared to $35.85 \%$ in the conventional storage.

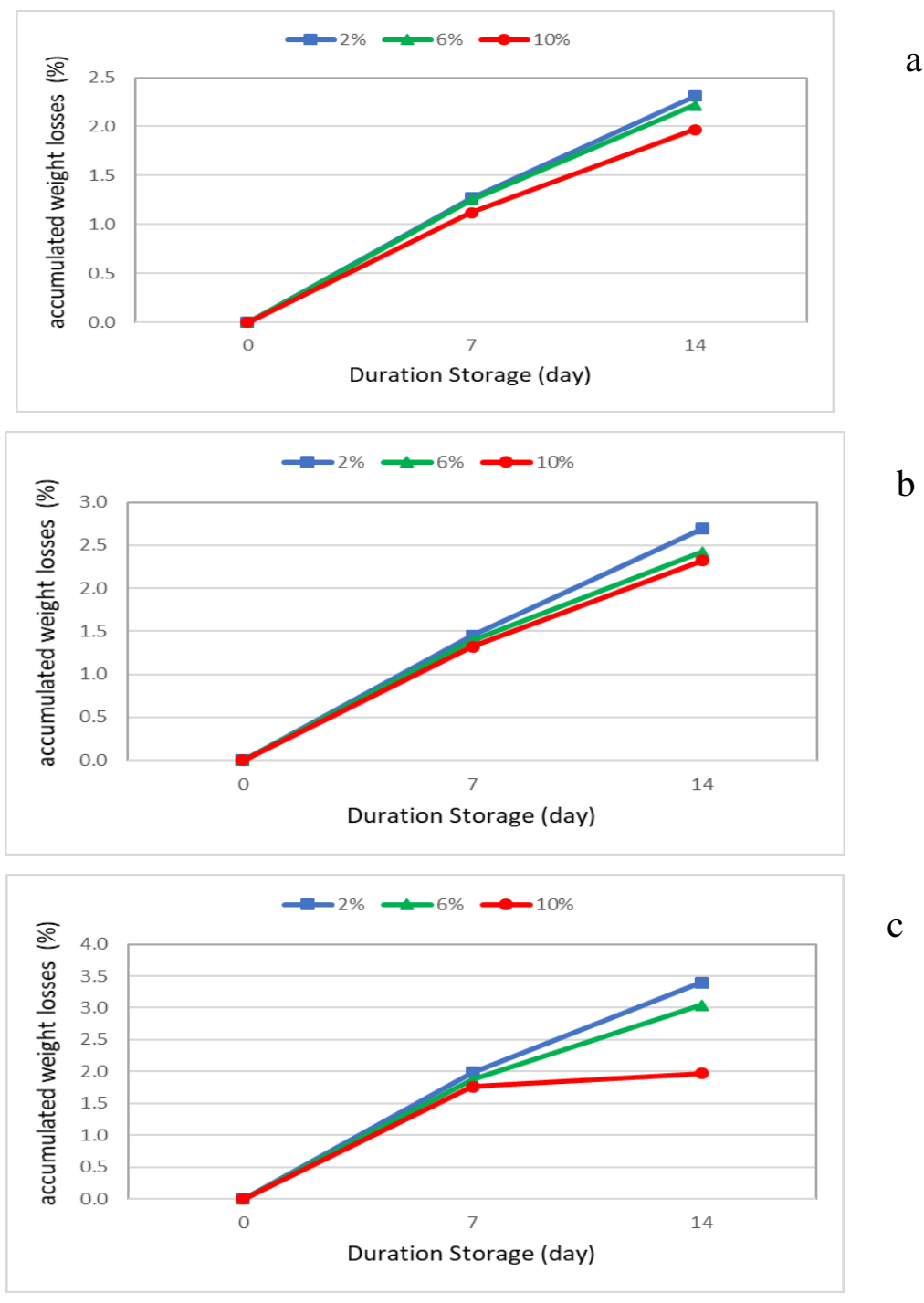

Figure (7): The effect of different $\mathrm{O}_{2}$ and $\mathrm{CO}_{2}$ levels on accumulated weight losses inside the package of fresh squash during storage.

Data in figure (8) shows the accumulated weight losses of squash during storage as affected by the perforation levels in package. The results indicated that the accumulated weight losses of squash increases with increasing during storage. It could be seen that the accumulated weight loss of squash increased from 0 to $2.43,0$ to 2.62 and 0 to $3.04 \%$, when 
the storage period increased from 0 to 14 days at 10, 20 and 30 punches packages, respectively.

The results also indicated the accumulated weight losses of squash increases with increasing perforation level surface area. It could be seen that the accumulated weight loss of squash increased from 1.36 to 1.73 and 2.43 to $3.04 \%$, when the perforation level surface area increased from 10 to 30 punches packages after 7 and 14 days, respectively. While it was compared $35 \%$ by the end of storage period (14 days) that stored traditionally.

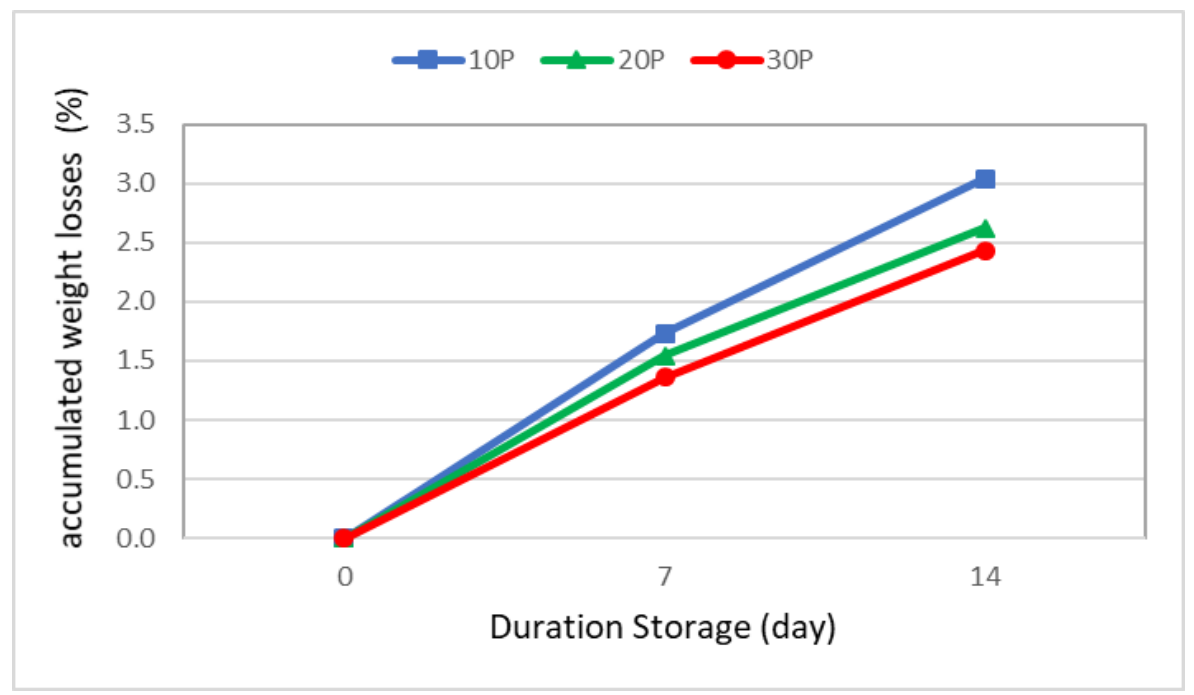

Figure (8): The effect of different perforation level surface area on the accumulated weight losses of squash during storage.

\subsection{Hardness of squash:}

Figures ( $9 \mathrm{a}, \mathrm{b}$ and $\mathrm{c}$ ) show the effect of $\mathrm{O} 2$ and $\mathrm{CO} 2$ level inside the package on the hardness of fresh squash during storage. It could be seen that the squash hardness slightly decreased with storage time, the MA storage had slight effect on the hardness, where it ranged from $6.1-5.9 \mathrm{~g}$ $\mathrm{cm}^{-2}$ depending on the $\mathrm{O}_{2}$ and $\mathrm{CO}_{2}$ levels.

Figure (10) shows the hardness of squash stored at different levels of performances (10, 20 and 30p), where, it hangs in changed slightly with storage time from 6.1 to $5.9 \mathrm{~g} \mathrm{~cm}^{-2}$. Squash stored soundly for 14 days with slight change in hardness. 

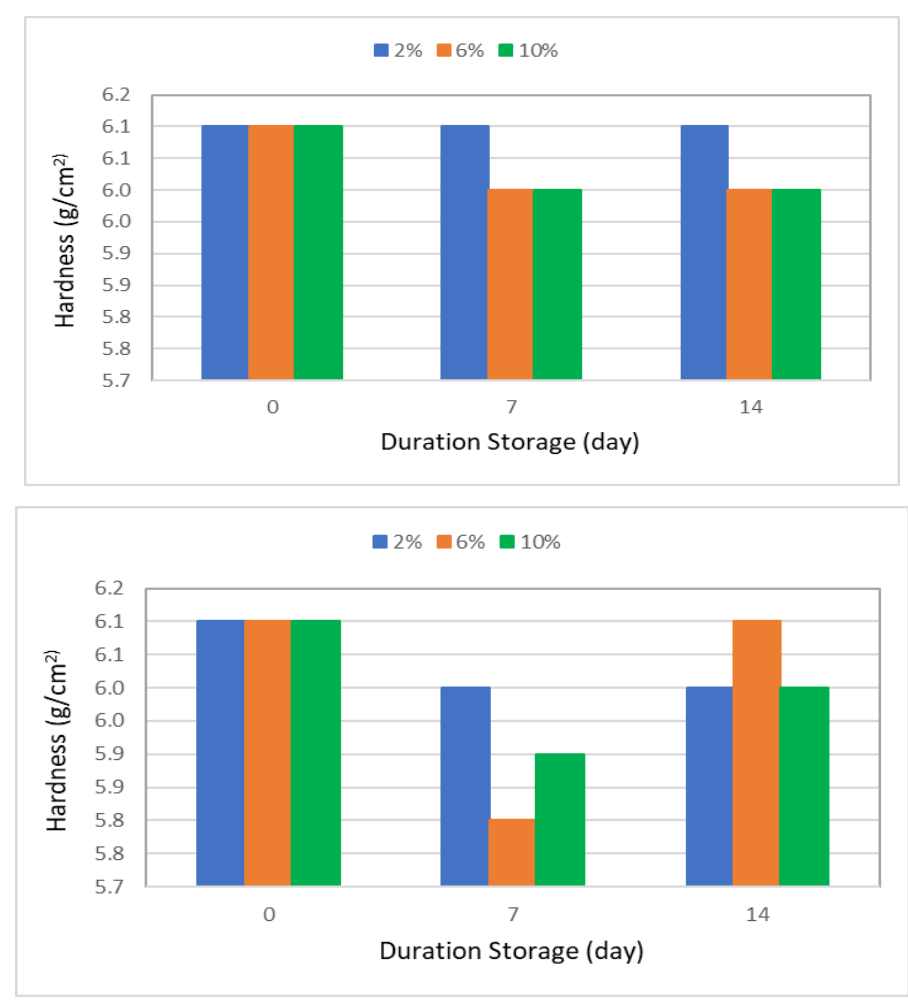

$\mathrm{b}$

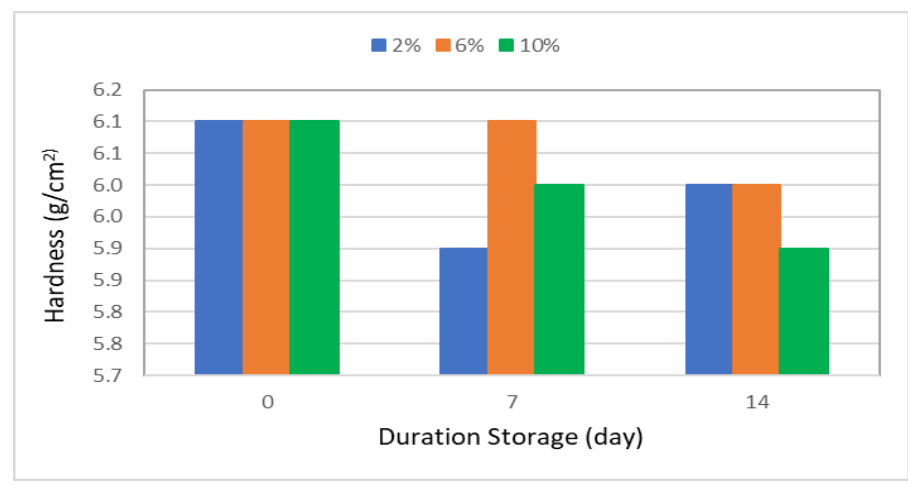

c

Figure (9): The effect of different $\mathrm{O}_{2}$ and $\mathrm{CO}_{2}$ levels on hardness of fresh squash during storage.

\subsection{Colour of squash:}

Figures (11 a, b and c) show the effect of different $\mathrm{O}_{2}$ and $\mathrm{CO}_{2}$ levels on colour $\left(\mathrm{L}^{*}\right)$ of squash during storage. The results indicated that the colour ( $\left.\mathrm{L}^{*}\right)$ of squash decreases with increasing $\mathrm{CO}_{2}$ level during storage period. It could be seen that, when the $\mathrm{CO}_{2}$ concentration increased from 2 to 
$10 \%$, the colour $\left(\mathrm{L}^{*}\right)$ of squash decreased from 62.18 to $58.11,62.18$ to 58.13 and 62.18 to 62.18 to 57.58 after 7 and 14 days, respectively at $1 \%$ $\mathrm{O}_{2}$ level. At $3 \% \mathrm{O}_{2}$ level, the colour $\left(\mathrm{L}^{*}\right)$ of squash decreased from 62.18 to $60.17,62.18$ to 58.31 and 62.18 to 58.04 after 7 and 14 days, respectively, when the $\mathrm{CO}_{2}$ concentration increased from 2 to $10 \%$. At $5 \% \mathrm{O}_{2}$ level, the colour $\left(\mathrm{L}^{*}\right)$ of squash decreased from 62.28 to 60.01, 62.18 to 56.26 and 62.18 to 56.02 after 7 and 14 days, respectively, when the $\mathrm{CO}_{2}$ concentration increased from 2 to $10 \%$.

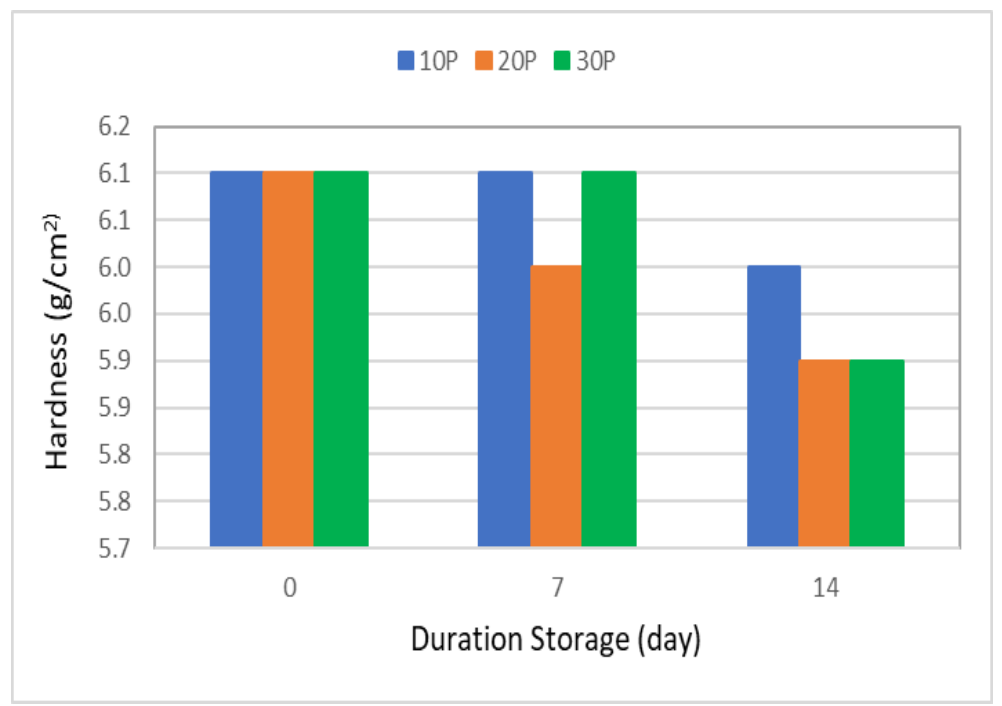

Figure (10): The effect of different perforation level on hardness of fresh squash during storage.

The results indicate that the colour $\left(\mathrm{L}^{*}\right)$ of squash fruits decreases with increasing drying period. It could be seen that the colour $\left(\mathrm{L}^{*}\right)$ of squash decreased from 62.18 to $57.94,62.18$ to 58.04 and 62.18 to 57.43 , when the storage period increased from 0 to 14 days at 1,3 and $5 \% \mathrm{O}_{2}$ levels, respectively.

Figure (12) shows the colour ( $\left.\mathrm{L}^{*}\right)$ of squash during storage as affected by the perforation levels in package. The results indicated that the colour $\left(\mathrm{L}^{*}\right)$ of squash decreases with increasing during storage. It could be seen that the colour $\left(\mathrm{L}^{*}\right)$ of squash decreased from 62.18 to $59.62,62.18$ to 6020 and 62.18 to 60.93 , when the storage period increased from 0 to 14 days at 10, 20 and 30 punches packages, respectively. 


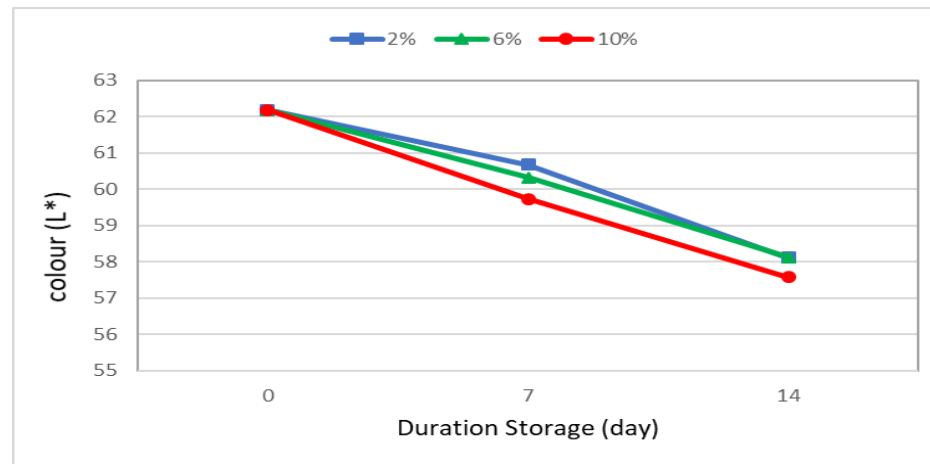

$\mathrm{a}$

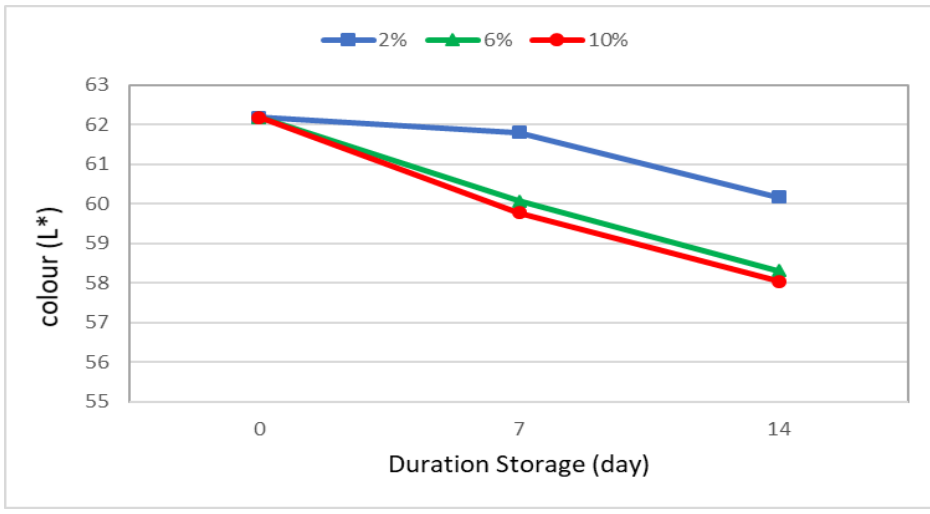

b

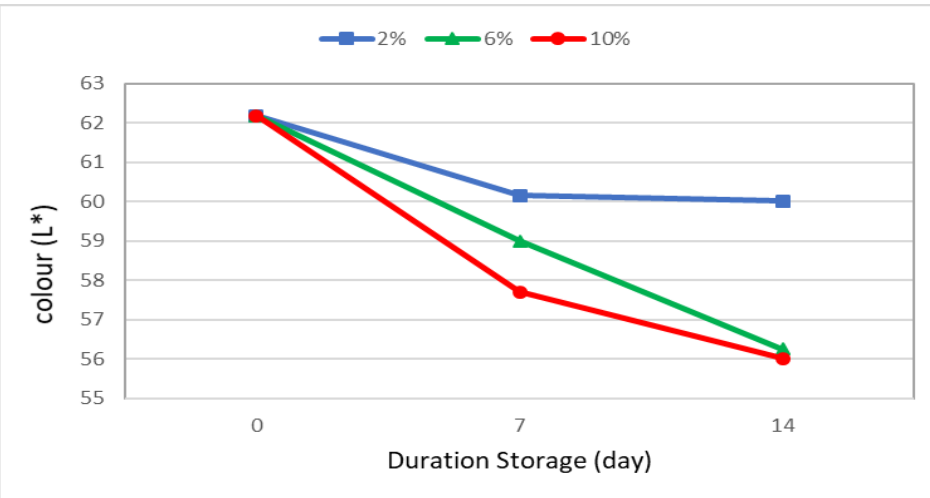

c

Figure (11): The effect of different $\mathrm{O}_{2}$ and $\mathrm{CO}_{2}$ levels on colour ( $\left.\mathrm{L}^{*}\right)$ of squash during storage.

The results also indicated the colour $\left(\mathrm{L}^{*}\right)$ of squash increases with increasing perforation level surface area. It could be seen that the colour $\left(\mathrm{L}^{*}\right)$ of squash increased from 60.39 to 61.53 and 59.62 to 60.93 , when the perforation level surface area increased from 10 to 30 punches packages after 7 and 14 days, respectively. 


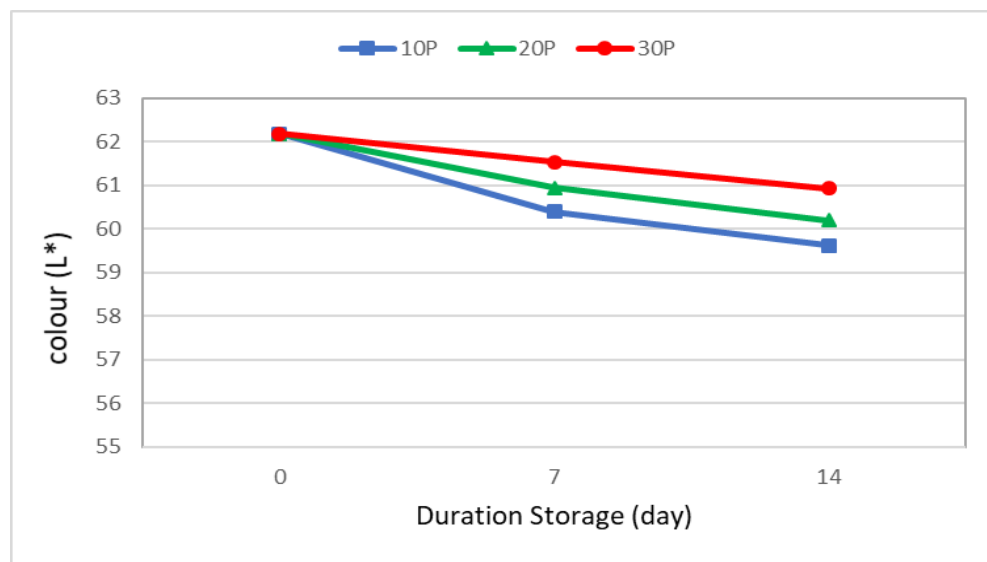

Figure (12): The colour $\left(\mathrm{L}^{*}\right)$ of squash during storage as affected by the perforation levels in package.

\subsection{Hue angle of squash:}

Figures (13 a, b and c) show the effect of different $\mathrm{O}_{2}$ and $\mathrm{CO}_{2}$ levels on hue angle of squash during storage. The results indicated that the hue angle of squash increases with increasing $\mathrm{CO}_{2}$ level during storage period. It could be seen that, when the $\mathrm{CO}_{2}$ concentration increased from 2 to $10 \%$, the hue angle of squash increased from 62.60 to $67.21,62.60$ to 65.47 and 62.60 to 64.52 after 7 and 14 days, respectively at $1 \% \mathrm{O}_{2}$ level. At $3 \% \mathrm{O}_{2}$ level, the hue angle of squash increased from 62.60 to 66.25 , 62.60 to 66.20 and 62.60 to 62.61 after 7 and 14 days, respectively, when the $\mathrm{CO}_{2}$ concentration increased from 2 to $10 \%$. At $5 \% \mathrm{O}_{2}$ level, the hue angle of squash increased from 62.60 to $65.92,62.60$ to 65.47 and 62.60 to 63.88 after 7 and 14 days, respectively, when the $\mathrm{CO}_{2}$ concentration increased from 2 to $10 \%$.

Figure (14) shows the hue angle of squash during storage as affected by the perforation levels in package. The results indicated that the hue angle of squash increases with increasing during storage. It could be seen that the hue angle of squash increased from $62.1867 .37,62.18$ to 67.56 and 62.18 to 68.31 , when the storage period increased from 0 to 14 days at 10 , 20 and 30 punches packages, respectively.

The results also indicated the hue angle of squash increases with increasing perforation level surface area. It could be seen that the hue angle of squash increased from 64.99 to 66.57 and 67.37 to 68.31 , when 
the perforation level surface area increased from 10 to 30 punches packages after 7 and 14 days, respectively.

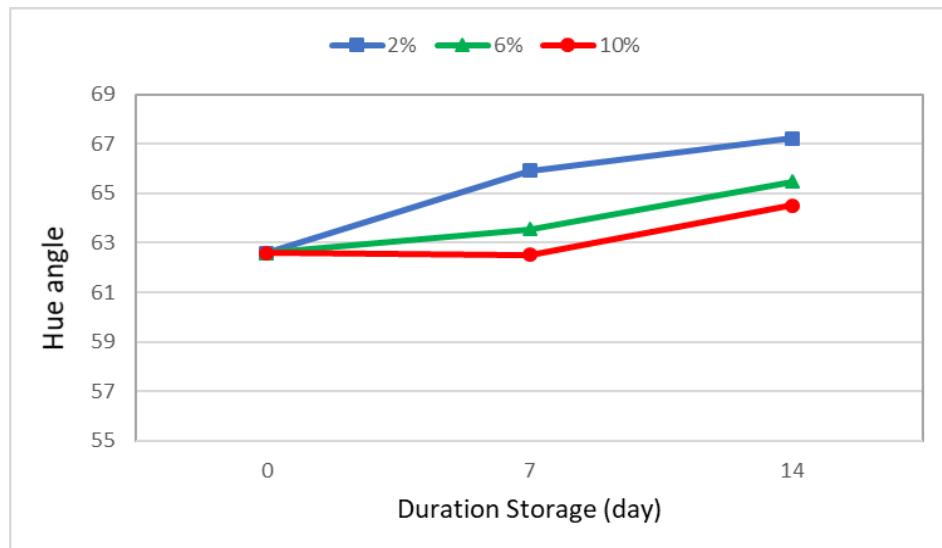

a

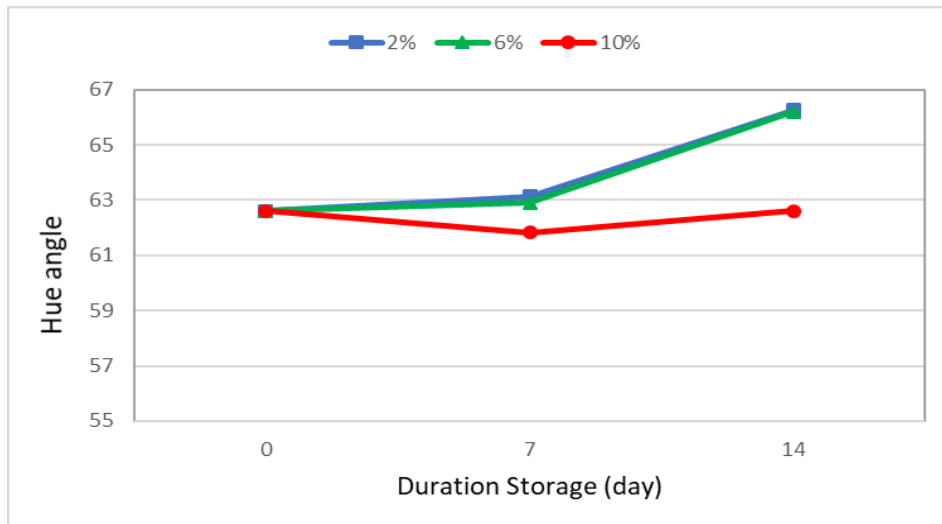

b

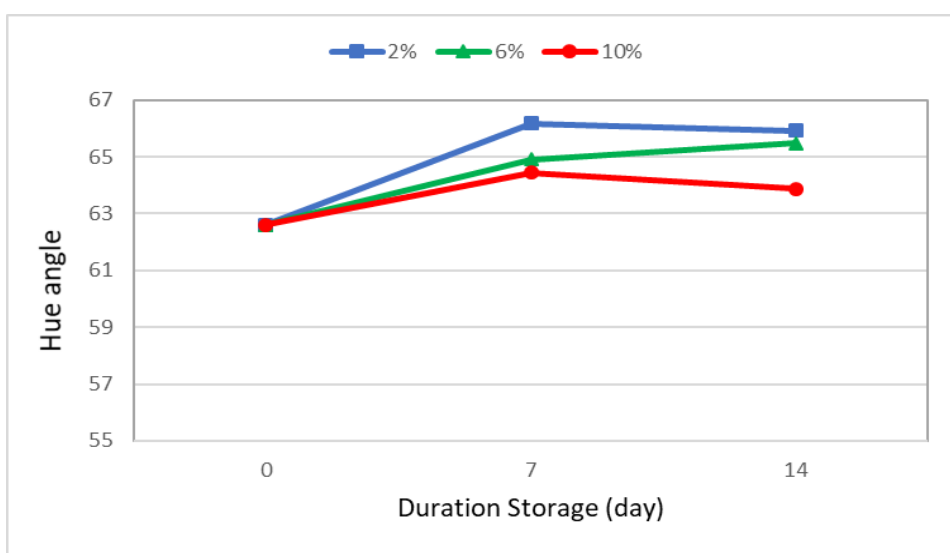

Figure (13): The effect of different $\mathrm{O}_{2}$ and $\mathrm{CO}_{2}$ levels on hue angle of squash during storage. 


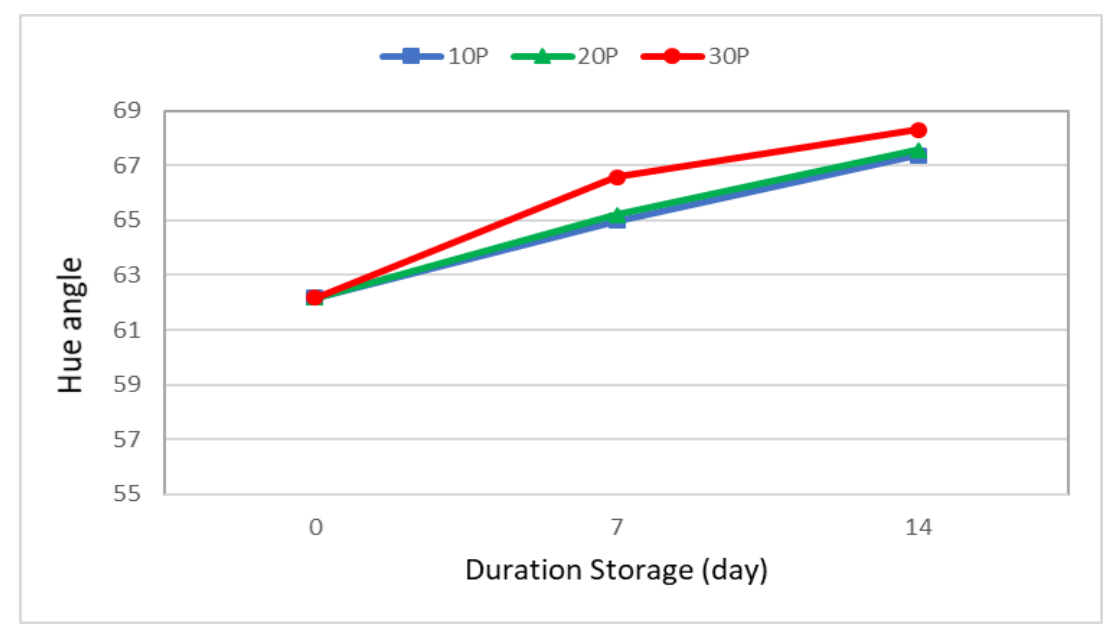

Figure (14): The hue angle of squash during storage as affected by the perforation levels in package.

\section{CONCLUSIONS}

An experimental study was carried out successively to study the effect of modified atmosphere storage on the quality of squash during storage. Squash fruits were stored at three levels of $\mathrm{O}_{2}$ concentrations (1, 3 and $5 \%$ ), three levels of $\mathrm{CO}_{2}$ concentrations (2, 6 and 10\%) and cold storage at $10{ }^{\circ} \mathrm{C}$ and $70 \%$ relative humidity as compared with storage in normal air in perforated and non-perforated packages. The obtained results can be summarized as follows:

- The concentration $\mathrm{CO}_{2}$ inside the package of fresh squash during storage ranged from 4.71 to $24.02 \%$ for all treatment.

- The concentration $\mathrm{O}_{2}$ changed from 1 to $1.63 \%$ at $1 \% \mathrm{O}_{2}$ with changing $\mathrm{CO}_{2}$ from $2-10 \%$, from $1.8-3.67 \%$ at $3 \%$ and $3.53-7.5 \%$ at $5 \% \mathrm{O}_{2}$.

- The ethylene concentration inside the package increased from 4.11 to $51.64,7.23$ to 86.50 and 18.37 to $126.68 \%$, when the storage period increased from 4 to 14 days at 1,3 and $5 \% \mathrm{O}_{2}$ levels, respectively.

- The accumulated weight loss of squash increased from 0 to 2.17, 0 to 2.48 and 0 to $2.80 \%$, when the storage period increased from 0 to 14 days at 1,3 and $5 \% \mathrm{O}_{2}$ levels, respectively.

- The squash hardness slightly decreased with storage time, the MA storage had slight effect on the hardness. 
- The colour $\left(\mathrm{L}^{*}\right)$ of squash decreases with increasing $\mathrm{CO}_{2}$ level during storage period. While, the hue angle of squash increases with increasing $\mathrm{CO}_{2}$ level during storage period.

\section{REFERENCES}

Barmore, C.R. (1987). Packing technology for fresh and minimally processed fruits and vegetables. Journal of Food Quality 10: 207217.

Chitarra, M.I.F. and Chitarra A.B. (2005). Pós-colheita de frutas e hortaliças: fisiologia e manuseio. 2 ed, UFLA, Lavras, P 785.

Emond, J.P. and Chau K.V. (1990). Use of perforation in modified atmosphere packaging. St. Joseph, USA: American Society of Agricultural Engineers (paper no. 90-6512).

Emond, J.P., Castaigne F., Toupin, C.J. and Desilets D. (1991). Mathematical modelling of gas exchange in modified atmosphere packaging. Transactions of the American Society of Agricultural Engineers, 34: 239-245.

Geeson, J., Browne K. and McKeown B. (1990). Storage rot of swede caused by Phytophthora sp. Plant Pathol., 39: 629-631.

Geeson, J.D., Browne K.M., Everson H.P. (1988). Storage diseases of carrots in East Anglia 1978-82, and the effects of some pre- and postharvest factors. Annals of Applied Biology, 112, 503-14.

Geeson, J.D., Browne K.M., Maddison KI., Shepherd J. and Guaraldi F. (1985). Modified atmosphere packaging to extend the shelf life of tomatoes. Journal of Food Techology 20: 339-349.

Izumi, H. and Watada A.E. (1995). Calcium treatment to maintain quality of zucchini squash slices. J. Food Sci. 60: 789-793.

Li, J., Carlson B.E. and Lacis A.A. (2014). Application of spectral analysis techniques in the inter-comparison of aerosol data, Part 4: Synthesized analysis of multisensor satellite and ground-based AOD measurements using combined maximum covariance analysis. Atmos. Meas. Tech., 7, 2531-2549, doi:10.5194/amt-72531-2014. 
Mahajan, P.V., Oliveira, F.A.R., Montanez, J.C. and Frias J. (2007). Development of user-friendly software for design of modified atmosphere packaging for fresh and fresh-cut produce. Innovative Food science and Emerging Technologies, 8: 84-92.

Mangaraj, S., Goswami T.K. and Mahajan, P.V. (2009). Applications of plastic films for modified atmosphere packaging of fruits and vegetables: a review. Food Engineering Reviews, 1: 133-158.

Mencarelli, F. 1987. Effect of high CO2 atmospheres on stored zucchini squash. J. Amer. Hort. Sci. 112: 985-988.

Mencarelli, F., Lipton, W.J., and Peterson, S.J. 1983. Responses of 'Zucchini' squash to storage in low-O2 atmospheres at chilling and non-chilling temperatures. J. Amer. Soc. Hort. Sci. 108: 884-890.

Mistriotis, A., Giannoulis A., Giannopoulos D. and Briassoulis D. (2011). Analysis of the effect of perforation on the permeability of biodegradable non-barrier films. 11th International Congress of Engineering and Food (ICEF11). Procedia Food Science, 1, 32-38.

Mitchell, F.G. (1992). Cooling horticultural commodities. II. Cooling methods. In: Kader AA, (ed.). Postharvest Technology of Horticultural Crops. Berkeley, CA: University of California, Division of Agr. Natural Resources, pub. 3311, p. 56-63.

Ryall, A.L. and Lipton W.J. (1979). Handling, Transportation and Storage of Fruits and Vegetables. Vol. 1. Vegetables and Melons. 2nd ed. Westport, CT: AVI.

Saltiveit, M.E. (2004). Respiratory metabolism. In: ARC, USDA agric. Handbook 66 revised. The Internet.

Silveira, A.C., Araneda C., Hinojosa A., and Escalona V.H. (2014). Effect of non- conventional modified atmosphere packaging on fresh cut watercress (Nasturtium officinale R. Br.) quality. Posth. Biol.

Technol.92:14-

20.http://dx.doi.org/10.1016/j.postharvbio.2013.12.012.

Wang, C.Y. and Ji, Z.L. 1989. Effect of low-oxygen storage on chilling injury and polyamines in zucchini squash. Sci. Hort. 39: 1-7. 
Weichmann, J. 1986. The effect of controlled-atmosphere storage on the sensory and nutritional quality of fruits and vegetables. Hort. Rev. 8: 101-127.

\section{الملخص العربى \\ تخزين ثمار الكوسة الطازجة فى عبوات ذات جو معدل \\ هبه رجب سيد احمد* ، عادل حامد بهنساوى** ، \\ طه حسن مختار عاشور*** و خالد سيد احمد ناجى***}

تهدف هذه الدراسة الى بحث تأثثر التخزين فى الاجو اء المعدلة على جودة والعمر التخزينى لثمار

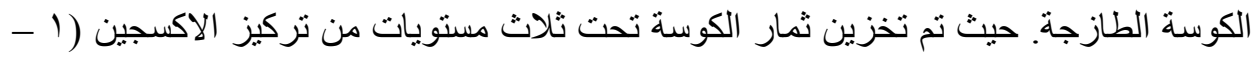

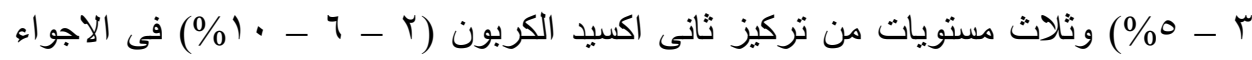

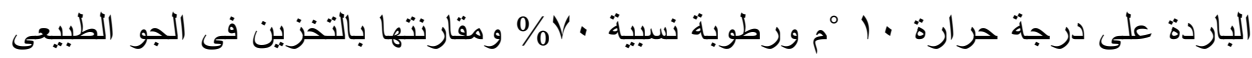

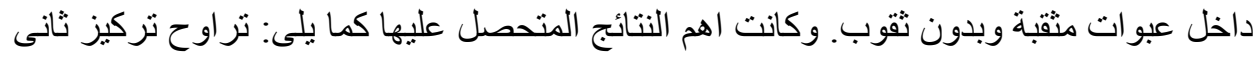

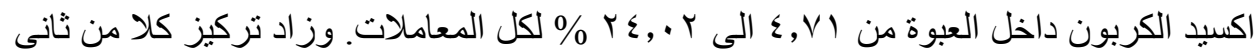

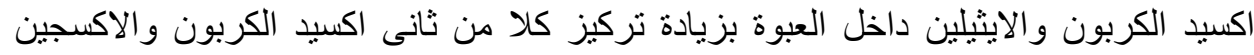

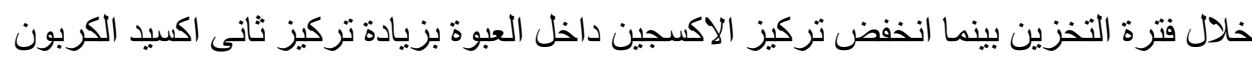

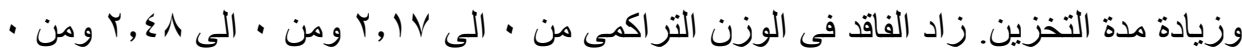

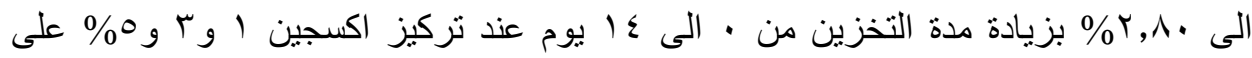

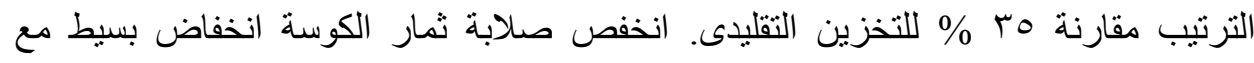
التخزين. انخفض لون ثمار الكوسة بزيادة تركيز ثانى اكسيد الكربون خلال مدة التخزين.

*مدرس مساعد الهندسة الزراعية _ كلية الزراعة - جامعة بنها

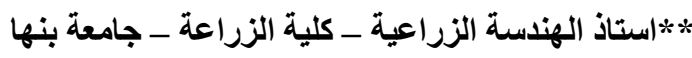
*** **يس بحوث ـ معهد تكنولوجيا الاغذية ـ المركز القومى للبحوث ـ مركز البحوثة الزرعية 